\title{
개발원조에 대한 대국민 여론조사 및 정부의 국제개발협력정책의 방향연구 ${ }^{1)}$
}

\author{
전승훈 · 김소원 한국개발전략연구소
}

\section{I. 머리말}

개발원조에 대한 공여국 국민의 지지는 원조의 정당성(legitimacy), 책임감(accountability), 효율 성(efficiency)을 제공하는 기반이 된다. 하지만, $\mathrm{OECD}$ 회원국 국민은 대부분 대외원조에 대해 긍 정적인 생각과 참여의지를 갖고 있음에도 불구하고 정부의 개발협력정책이나 국제사회의 원조동향 에 대해서는 잘 알지 못하는 것으로 조사되었다(Mc Donnell et al., 2003). 이는 개발원조에 대한 원조습득이 대부분 대중매체의 단편적인 정보제공에 의존하기 때문인 것으로 보이는데, 정부 차원 에서 체계적인 정보제공 시스템을 구축하고, 시민사회의 참여도를 높여 원조정책 및 개혁의 일관성 과 효과성을 확보할 필요가 제기된다. 이를 통해 원조비용을 충당하는 데 대한 납세자의 책임감도 높아질 수 있을 것이다.

한편, $\mathrm{OECD} / \mathrm{DAC}$ 가입을 필두로 선진공여국으로 발돋움하고자 하는 한국의 입장에서, 한국 국민 의 대외원조에 대한 인식을 파악하고 정부정책의 개선점을 도출하는 일은 보다 중요한 의미를 지닌 다. 현재 한국은 국제사회의 원조규범에 부합하는 개발원조 정책을 추구해야 함과 동시에, 납세자 이자 행위자인 국민의 지지 기반을 확보해야 하는 두 가지 과제를 갖고 있다. 이를 성공적으로 수행 하기 위해서는 우선 개발원조에 대한 국민 의식을 체계적으로 파악 및 분석하고 그에 기반한 개발 협력 정책 방향을 제언하는 것이 필요하다. 이러한 인식에 입각하여, 이 글에서는 한국개발전략연 구소가 2008년에 수행한 「개발원조에 대한 대국민 여론조사 및 국제개발협력 정책의 방향연구」 (전승훈 외, 2008)의 내용 및 결과를 소개하여, 논의의 장을 넓히는데 기여하고자 한다.

\section{II. 연구 범위 및 방법}

\section{1. 연구 범위}

1) 이 글은 외교통상부/국제개발학회의 위탁으로 2008년 8월 9월 사이에 한국개발전략연구소가 수행한 「개발원조에 대한 대국민 여론조사 및 정부의 국제개발협력 정책의 방향 연구」(전승훈, 유철, 김익기, 이주현)를 정리·요약한 것이다. 
동 연구의 범위는 개발원조 정책과 관련된 주요 이슈를 폭넓게 다루도록 구성되었다. 크게 개발원 조에 대한 국민의 의식 및 태도에 관한 조사와 개발협력 정책방향 연구로 나뉘는데, 전자는 다시 4 가지 분야, “ 1 .개발원조에 대한 인지도, 2. 개발원조 정책의 선호도 및 우선순위, 3. 개발원조의 효과 성, 4. 개발원조에의 참여 및 정보의 접근성'으로 구분하고, 분야마다 세부 질문(총 25 문항)을 만들 어 조사를 하였다. 이와 같이 도출된 국민의 의식 및 태도에 대한 조사 결과를 바탕으로 문헌 조사 및 기존 여론 조사에 대한 분석을 통하여 개발협력 정책방향에 대한 연구를 진행하였다.

\section{2. 연구 방법}

우선 개발원조에 대한 국민 의식 및 태도에 관하여 정확한 자료를 얻기 위해 여론조사 표 설계 및 조사방법에서부터 분석에 이르기까지 별도 여론조사 전문기관의 도움을 받아 전문성 및 신뢰성을 확보할 수 있도록 하였다. 여론조사는 25 개 문항, 면접설문 방식으로 설계되어 수행되었는데, 설 문지 문항수가 적을 경우 사실에 대한 기술(descriptive) 수준에서 끝날 수 있으므로, 과거에 시행 한 여론조사보다 충분한 수의 질문을 하여 대외원조에 대해 다각적이고도 깊이 있는 조사를 실시하 도록 하였다. 또한, 전화 설문이나 온라인 조사와 같은 여론조사 방식이 아닌 면접 설문 방식을 택 하여 여론조사의 신뢰성 및 효과성을 제고하였다. 조사 대상자는 한정된 재원의 제약상 500 명이었 으며, 성별, 나이, 직업, 거주지, 교육 수준, 소득 수준, 개도국여행경험 여부 등으로 분류하여 기본 요인(factor)에 따른 응답의 변화를 분석할 수 있도록 하였다. 조사는 개별 방문 면접조사 방법을 통하여 이루어졌다. 전국 16 개 시도별로 표본할당을 한 후, 무작위 가구를 방문하여 면접조사를 진 행하는 방법으로 이루어졌다.

한편, 개발협력 정책방향에 대한 연구는 개발원조에 대한 위와 같은 여론조사 결과를 바탕으로 선 진국의 여론조사 내용 및 개발협력 정책에 대한 문헌 조사에 의한 비교 분석을 통하여 바람직한 개 발협력 정책방향을 모색하였다. 특히 비교 분석을 위하여 과거 국내의 개발원조 관련 여론조사 결 과 및 선진공여국이 시행한 개발원조 관련 여론조사 결과를 본 여론조사 결과와 비교 분석하고, 그 에 따른 정책 방향에 시사점(implication)을 도출하고자 하였다.

〈조사 개요〉

\begin{tabular}{l|c}
\hline \hline \multicolumn{1}{c|}{ 구 분 } & 내 용 \\
\hline \hline 1) 조사 대상 & 전국의 만 19세 이상 성인 남녀 \\
\hline 2) 표본 크기 & 500명 \\
\hline 3) 표본추출 방법 & 지역별, 성별, 연령별 인구비에 의한 비례할당 \\
\hline 4) 조사 방법 & 개별 방문 면접 조사 \\
\hline 5) 조사 일시 & 2008년 8월 5일 8월 18일(15일간) \\
\hline 6) 조사 도구 & 구조화된 질문지(Structured Questionnaire) \\
\hline 7) 표본 오차 & \pm 4.38\%P (95\% 신뢰수준) \\
\hline 8) 조사 기관 & 한국갤럽 \\
\hline
\end{tabular}




\section{III. 여론조사의 결과}

\section{1. 개발원조에 대한 인지도}

개발원조에 대한 인지도는 $50.8 \%$ 로 즉 조사 대상자의 반 정도가 개발원조를 사실을 인지하고 있었 다. 그 중 개발도상국에 대외원조를 하는 이유로는, 응답자 10 명 중 3 명이 '과거에 우리도 원조를 받았기 때문'(30.0\%)이라고 생각하는 것으로 나타났다. 선진국의 빈곤국가에 대한 원조가 국제사 회의 빈곤감소에 ‘공헌했다’라는 응답은 $70.2 \%$ 로 긍정적인 반응이 나타났다. 한편, 세계 지역별 빈 곤의 심각 정도에 있어서는, 응답자의 $86.2 \%$ 가 '아프리카' 지역의 빈곤이 가장 심각하다고 생각하 고 있으며, 그다음이 '동남아시아' 지역(29.2\%)으로 꼽혔다.

\section{〈그림 1〉 개발원조 인지도에 대한 조사항목 및 응답률}

1) 한국의 대외원조사실에 대한 인지

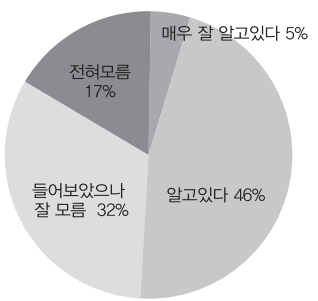

4) 대외원조를 하는 이유

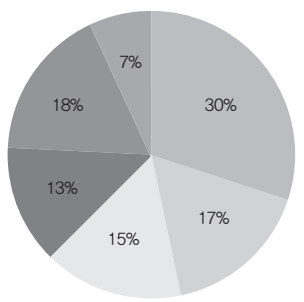

- 과거에 우리도 원조를 받아서

- 국제사회 안정과 세계평화 기여

인도적 의무이므로

- 외교적 국가이익도모 위해서

- 경제적 이익에 도움되므로

핌 대외원조 하지않으면 국제적으로 고립
2) 과거 한국이 원조를 받은 사실 인지여부

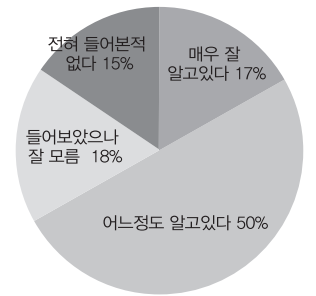

5) 선진국의 대외원조가 개도국 빈곤감소에 기여했는가

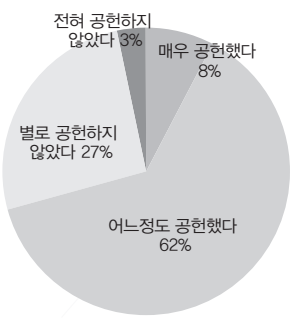

2) 천년개발목표(MDGs)에 대한 인지

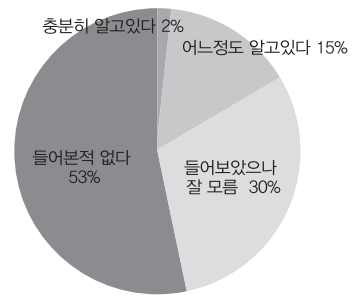

6) 지역별 빈곤의 심각성

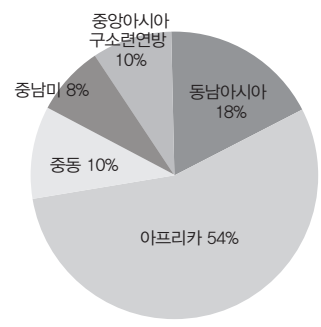




\section{2. 개발원조에 대한 선호도 및 정책적 우선순위}

한국의 대외원조 규모에 대한 의견을 보면, 응답자의 $44.0 \%$ 는 '적절하다’라는 생각을 하고 있으며, 원조증액 계획에 대해서는 응답자의 절반 정도(53.4\%)가 '현 수준을 유지해야 한다’고 응답하였다. 한편, 한국의 대외원조 규모를 '축소 또는 지원중단’ 응답자를 대상으로 그 이유를 조사한 결과, 10 명 중 7명은 ‘우리나라 경제상황이 좋지 않기 때문'(71.0\%)으로 응답하여 대외원조에 있어서 국내 경제상황이 가장 변수인 것으로 보인다. 한국의 대외원조 효과를 극대화하기 위해 가장 우선적으 로 집중해야 할 분야로는 응답자의 $41.8 \%$ 가 '보건 및 의료개선’이라고 응답하였으며, 가장 중점적 으로 제공해야 하는 지역에 관해서는 '아프리카’, ‘동남아시아’ 지역 순으로 뽑았다. 한편, 2010년 $\mathrm{OECD}$ 개발원조위원회 $(\mathrm{DAC})$ 가입 추진 계획에 대해 응답자 10 명 중 2 명 정도만이 알고 있는 것으 로 나타났으며, 가입 효과로는 응답자의 절반 이상(69.6\%)이 긍정적인 효과를 예상하였다.

\section{〈그림 2〉 개발원조 정책의 선호도 및 우선순위에 대한 조사항목 및 응답률}
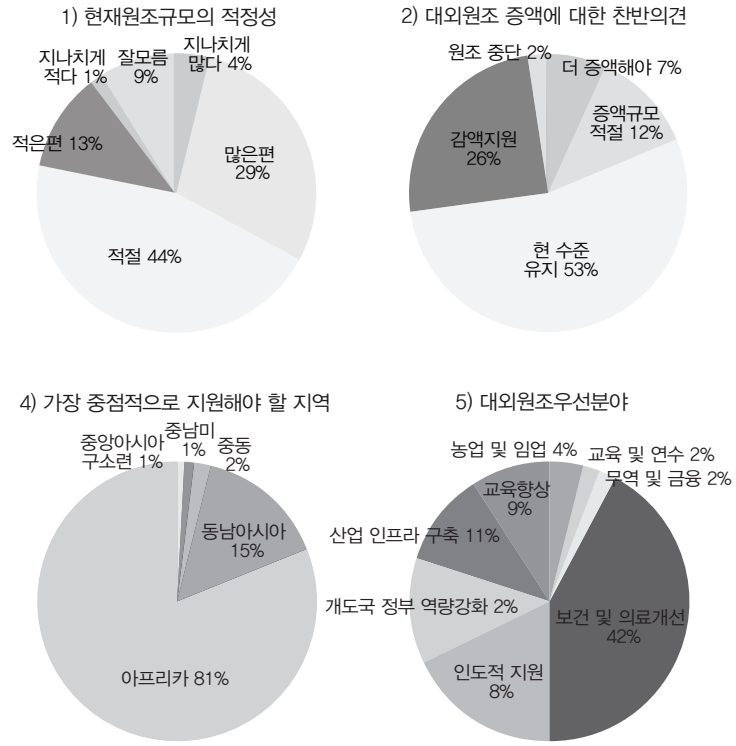

3) 대외원조 규모축소 또는 중단에 대한 이유

6) $\mathrm{OECD/DAC}$ 가입추진에 대한 인지도 7) $\mathrm{OECD/DAC}$ 가입의 기대효과에 대한 의견

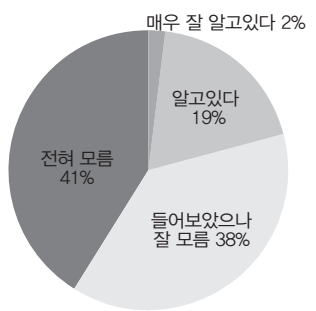

플 우리나라의 경제상황이 좋지 않으므로 내가 내야할 세금부담이 커지므로 개발도상국 빈곤감소에 도움되지 못하므로 - 외교관계나 경제이익에 도움되지 못하므로 지지원방식이나 관리가 효과적이지 못하므로

\section{3. 개발원조의 효과성}

효과성에 대한 항목에서 한국의 대외원조에 대해서 긍정적인 인식이 많았으며, 개발도상국의 발전 에 '기여한다'는 응답이 $76.8 \%$, 국익에 '기여한다'는 응답이 $71.8 \%$ 로 응답자 10 명 중 7 명이 대외 원조효과에 긍정적이었다. 한국의 대외원조가 국익에 가장 기여하는 분야로는 응답자의 절반 이상 (52.6\%)이 '국제사회에서 우리나라의 국가 이미지 및 국제적 지위 향상'이라고 생각하고 있었다. 
개발원조 효과성 증대를 위해 가장 중요하다고 생각하는 사항으로는, '대외원조 사업을 한국의 발 전경험을 바탕으로 한 기술협력 위주로 시행해야 한다’라는 응답을 가장 많이(44\%) 하고, 그 다음 이 ‘원조정책 및 사업추진 과정에서의 투명성’ $(25.6 \%)$ 이었다. 한편, 한국의 원조정책 수립 및 사업 추진 과정에서의 투명성에 대해, 조사대상자의 $44.4 \%$ 는 '투명하지 않다', $21.6 \%$ 는 '투명하다'라고 응답하였다.

\section{〈그림 3〉 개발원조의 효과성에 대한 조사항목 및 응답률}
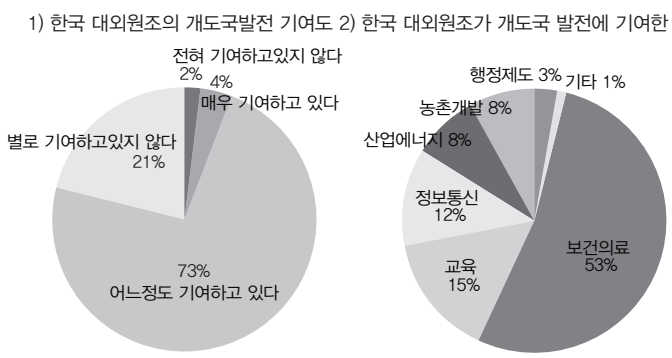

3) 한국 대외원조가 개도국 발전에

4) 한국의 대외원조가 국익에 기여하는 정도 기여하지 못하는 이유

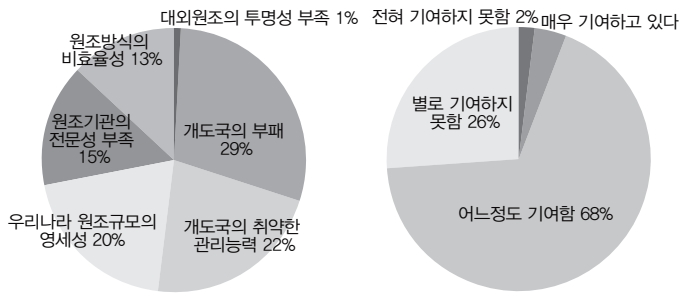

5) 국익에 가장 기여하는 분야

6) 개발원조의 효과성 증진을 위해

7) 개발원조정책수립 및 사업 추진의 투명성 가장 중요한 사항
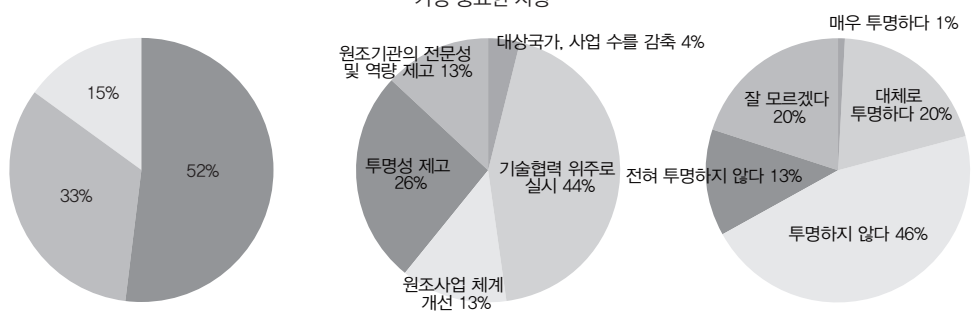

- 국제삭ㅎㅎ에에서 우리나ㄹㅏㅏㅇㅢ

- 대외원조 대상국가와의 정치, 외교적 협력관례 증진

자원확보, 시장개척 등 경제관계 확대

\section{4. 참여도 및 정보 접근성}

응답자 개인의 빈곤국가 지원경험 여부를 조사한 결과, 대부분 지원경험이 없는 것으로 나타났으 나, 앞으로 빈곤국 원조와 관련된 활동에 대해 응답자의 $48.8 \%$ 가 참여의향이 있다고 응답하였다. 대외원조와 관련하여 알고 싶은 정보로 응답자의 $40.4 \%$ 가 '원조가 피원조국 정부에 의해 제대로 쓰이고 있는지 여부’라고 응답하였고, $33.4 \%$ 는 ‘원조사업이 피원조국의 빈곤개선에 어느 정도 기 여하는지 여부’를 지적하였다. 대외원조 관련 정보를 얻을 수 있는 가장 효과적인 방법으로 ‘텔레비 전'(46.4\%), ‘인터넷’(36.8\%), ‘정부 및 원조기관의 간행물이나 웹사이트' $(2.8 \%)$, 'NGO 팸플릿, 웹사이트' $(1.0 \%)$ 등의 순서로 지적하고 있었다. 기관 차원의 적극적인 방안 마련이 필요할 것으로 파악되고 있다. 


\section{〈그림 4〉참여도 및 정보 접근성에 대한 조사 항목 및 응답률}

1) 응답자의 원조 관련 참여경험 및 향후 참여의향

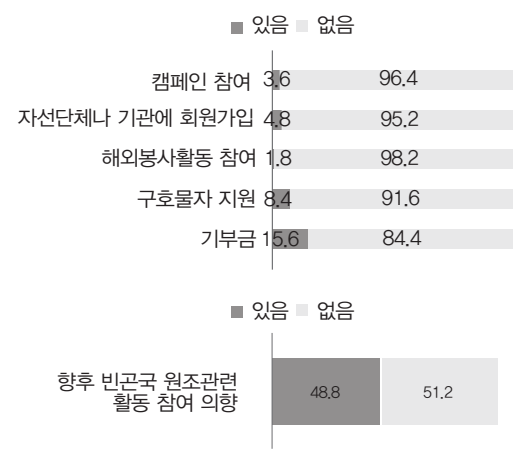

2) 얻고 싶은 원조관련 정보

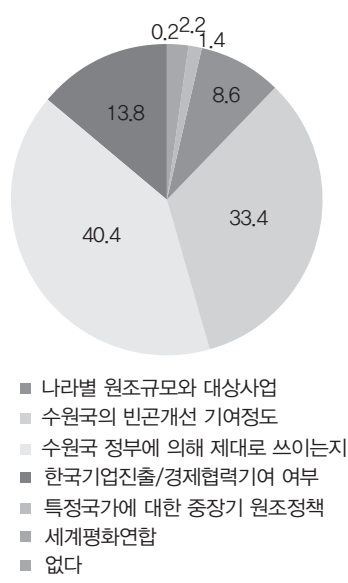

3) 원조관련 정보를 얻는 효과적인 방법

정부 간행물, 웹사이트 $3 \% \mathrm{NGO}$ 팸플릿, 웹사이트 $1 \%$

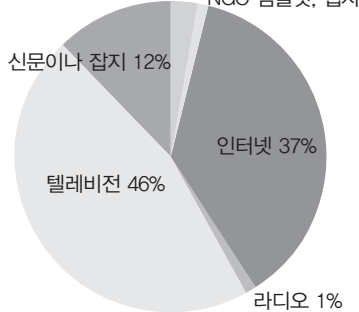

\section{IV. 정책적 시사점}

\section{1. 개발원조에 대한 인지도}

개발원조는 정부가 제공하는 것이지만, 재원은 일반 국민인 납세자들이 제공하는 것이며, 개발원조 사업의 전달이 국민의 참여를 통해 이루어지는 것이다. 따라서 개발원조에 대한 국민의 의식 또는 태도는 아주 중요하며, 특히 개발원조에 대한 국민의 인지도는 개발원조에 대한 국민의 의식 또는 태도 형성의 첫걸음으로서 의미가 있다. 이러한 중요성을 가지는 개발원조에 대한 인지도에 있어서 응답자의 약 절반이 이를 인지하는 수준에 그치고 있고, 원조활동에 참여한 경험이 선진국에 비하 여 크게 뒤짐은 그리 만족스러운 결과라고 보기 어렵다. 더욱이 국제사회의 이미지가 장래 생존의 결정적인 요소가 되는 여건에서 개발원조가 국제사회의 이미지 형성에 중요한 역할을 하는 점을 감 안할 때, 한국 국민은 개발원조에 대하여 이보다 훨씬 긍정적이고 적극적인 태도를 가질 것이 요구 된다고 할 것이다.

이를 위해서는 개발원조에 대한 홍보도 중요하지만, 무엇보다 원조사업에 대한 참여를 통하여 원조 에 대한 인지도를 높이고 보다 긍정적인 태도형성이 이루어지도록 하는 것이 바람직하다. 원조사 업에 있어서 보다 많은 전문가와 자원 봉사자들이 참여할 수 있도록 원조사업 수행의 문호를 과감 하게 확대할 필요가 있다. 즉, 원조사업의 수립, 집행 및 평가의 전 과정을 통하여 민관협력(Public Private Partnership)이 강화되도록 하는 것이다. 


\section{2. 개발원조 정책 선호도 및 정책 우선순위}

\section{1) 개발원조의 규모}

이번 조사에 있어서 대외원조의 규모에 대한 여론은 아주 긍정적이거나 부정적인 것은 아닌 것으 로 나타났다. 어느 정도의 $\mathrm{ODA}$ 가 적정 수준인가 하는 문제는 개발원조에 있어서 가장 핵심적인 정 책이슈 중 하나이다. 대외원조의 규모는 일반 여론보다는 국제사회에서의 위상과 책무, 재정적 여 건, 장래의 국가적 이익 등을 종합적으로 고려하여 결정해야 할 것이다. 우리 정부의 연간 대외원조 총액은 1987년 이래 꾸준히 증가하여 2007년 GNI 대비 $0.07 \%$ 에 해당하는 6.7억 달러에 이르렀 고 2008년 0.1\%를 달성할 전망이다. 그럼에도, 우리나라의 GNI 대비 ODA 규모는 국제사회의 권 고 기준(0.7\%)에 크게 못 미칠 뿐 아니라 여타 $\mathrm{OECD/DAC}$ 회원국의 평균(2007년 기준, $0.28 \%$ 과 비교해도 뒤떨어진다. ODA 확대는 연성국력(soft power)의 확대를 의미하며, 국제무대에서 우리 나라의 영향력을 증가시켜준다는 면에서도 UN의 권고에 부합하는 지속적인 확대를 추구해야 한다.

이러한 관점에서 볼 때, 향후 정책당국은 일반 국민이 보다 긍정적인 개발원조에 대한 태도를 가 질 수 있도록 개발원조의 성과를 높이는 동시에 $\mathrm{PPP}$ 를 확대하고 홍보 및 정보제공도 보다 확대하 여야 할 것이다. 경제불황기에도 안정적인 원조증액이 가능할 것인가에 대한 좋은 예가 아일랜드이 다. 아일랜드는 $\mathrm{NGO}$ 주도의 개발원조 교육과 정부의 적극적인 노력으로, 국민의 $90 \%$ 가 적극적으 로 원조를 지지하며, 1980 90년의 경제불황기에도 안정적인 원조를 가능케 하였다. 이는 우리에 게 중요한 시사점을 제공하고 있다(“국제 ODA동향”, 경협조사자료 P-2, p. 12).

\section{2) 지역별 우선순위}

우리나라의 양자 간 $\mathrm{ODA}$ 는 아시아 지역에 집중됐으나 최근 감소하는 추세이고 아프리카에 대한 지원 비중이 확대되고 있다. 2006년 양자 간 ODA는 아시아(40\%), 중동(20\%), 아프리카(13\%) 순 으로 아프리카가 받는 원조는 빈곤의 심각성에 비해 현저히 떨어진다. 아시아가 우리나라의 가장 큰 원조를 받는 이유는 우리나라의 국익과 가장 관계가 깊은 지역이기 때문이다. 이웃 일본도 비슷 한 맥락에서 아시아에 가장 큰 우선순위를 두고 있다.

이러한 상황이 전 세계적으로 유사하게 나타나는 것은, 원조제공의 동기가 순수한 인도적 차원뿐 아니라 원조공여국의 이익을 우선으로 고려한 것이기 때문이기도 하다. 이러한 경향은 UN의 MDG 로 대표되는 국제사회의 지구촌 빈곤감소에 대한 의지를 두고 볼 때, 향후 상당 부분 시정될 것으로 보인다. 우리나라 국민의 대부분이 아프리카 $(81 \%)$ 를 원조의 최우선 순위에 두고 있고 그다음이 아 시아(15.2\%)를 꼽은 것도, 향후 아프리카에 대한 ODA 비중을 늘리는 것의 근거가 될 수 있을 것이다. 


\section{3) 분야별 우선순위}

1987 2008.6 기간 중 우리나라의 ODA 분야별 집행 누계에 따르면, 보건과 교육은 각각 10.1\%, $7.4 \%$ 를 차지하고 있다 “국제 ODA동향”, 경협조사자료 P-2, p.46). 1991 2006년 동안 우리나 라의 무상원조는 행정제도, 교육, 보건의료에 각각 $20 \%, 15 \%, 15 \%$ 가 지원되었고, 유상원조는 산 업에너지, 보건의료, 정보통신에 각각 $40 \%, 20 \%, 20 \%$ 가 지원되어 보건의료에 대한 지원은 그 필 요성에 비해 상대적으로 미흡한 편이지만, 그 비중은 점차 확대되어가는 추세이다.

보건 및 의료분야에 대한 우선순위가 높게 나타난 것은 보건 - 의료 분야에 대한 정부의 대외지원 소식을 국민이 미디어를 통하여 자주 접한 것뿐 아니라, 이 분야를 국민이 중요하고 긴급한 분야로 인식하고 있기 때문이기도 할 것이다. 질병, 재난, 분쟁 방지는 인간의 생존에 가장 절실한 분야이 다. 아프리카의 창궐하는 질병 예방과 치료, 지구상 재난 발생 시 구호, 중동 - 아프리카 등에서의 분쟁 시 난민보호나 구호, 건설 물자 지원 등에 더욱 큰 정책 우선순위를 들 필요가 있다. 그 뒤를 잇는 정부역량강화, 산업인프라 구축, 교육향상 등은 개발도상국의 장기적 발전을 위한 포석, 곧 행 정적, 산업적, 교육적 인프라에 해당하는 분야로 이 분야에 대한 지원은 개발도상국이 장기적으로 홀로 설 수 있는 기반을 마련해줄 것이다. 질병, 재난 방지 등 긴급한 필요와 장기적 홀로서기를 위 한 인프라 지원 중 어느 편에 더 우선순위를 둘 것인가 하는 문제는 쉽게 결론이 나지 않는 문제이 고 양쪽이 다 중요하다 할 수 있으나, 가장 긴박한 필요성이 있고 인간의 생명과 관계가 있는 보건, 의료, 재난 방지를 위한 지원에 원조의 최우선 순위를 두어야 할 것으로 본다.

\section{4) OECD/DAC 가입}

우리 정부는 2010년까지 선진공여국 그룹인 $\mathrm{OECD}$ 개발원조위원회(DAC) 가입을 추진 중이다. 우 리나라가 $\mathrm{OECD} / \mathrm{DAC}$ 에 가입하는 것에 대해 아직 국민의 인지도가 높지 않지만, 국민 대부분이 긍 정적으로 평가하는 점은 고무적이다. $\mathrm{DAC}$ 가입에 대한 정부의 계획과 국민의 의견이 일치하므로 $\mathrm{DAC}$ 가입은 순조롭게 추진해 나가는 데 보다 탄력을 받을 수 있을 것으로 보인다.

$\mathrm{DAC}$ 가입 필요성과 관련하여 $\mathrm{DAC}$ 가입의 이점을 홍보할 필요가 있다. 곧, $\mathrm{DAC}$ 는 세계원조의 $90 \%$ 이상을 제공하는 22 개 선진공여국 그룹으로 국제개발협력 분야에서 큰 영향력을 행사하고 개 발 분야 논의를 주도하고 있는 바, $\mathrm{DAC}$ 를 중심으로 이루어지는 국제사회의 원조체제 및 규범 형성 에 참여하여 우리의 입장과 이해관계를 반영할 필요가 있다. 또 개발, 기후 변화, 에너지, 자원, 이 민, 식량 등 개발협력과 관련된 주요 이슈의 결정 과정에 우리나라가 참여할 기회를 확대해야 한다. $\mathrm{DAC}$ 에 가입하기 위해서는 $\mathrm{ODA}$ 에 관해 일정 기준을 맞추어야 함을 홍보할 필요가 있다. 


\section{3. 원조의 효과성}

\section{1) 원조의 효과성 제고}

개발원조 효과성을 위해 가장 중요한 사항을 묻는 설문에 우리나라의 발전경험을 바탕으로 한 기술 협력 위주로 시행해야 한다는 응답이 가장 높게 나타났고 원조사업체계, 원조의 투명성, 원조기관 의 전문성과 역량을 높여야 한다는 의견도 높게 나타났다.

우리나라의 발전경험을 바탕으로 한 기술협력은 우리나라가 보유하고 있는 독특한 비교우위에 해 당한다. 우리나라는 개발도상국에서 선진국으로 진입했거나 진입하고 있는 제 1 세대 신흥공업국의 대표주자이다. 많은 개발도상국은 자신의 발전을 위해 우리나라를 벤치마킹하고 있다. 이러한 관 점에서 우리나라는 상당한 국제적 지위와 위신을 갖고 있고, 더불어 우리의 개발경험을 효과적으 로 개발도상국에 전수할 책임도 있다. 우리 국민 또한 한국의 발전경험을 바탕으로 한 개발원조 형 태에 지지를 하고 있는 바, 한국의 발전경험을 체계적으로 모델화할 수 있도록 데이터베이스를 구 축하고 대 개도국 전문가 파견 형태의 개발협력 컨설팅 분야를 육성할 필요가 있다. 이를 통해 한국 의 발전경험에 기초한 개발원조 수행을 통하여 선진공여국과의 차별성 및 국제사회에서의 경쟁력 을 확보할 뿐 아니라 개도국에 대한 기여도도 높여야 할 것이다. 한국의 발전경험에 기초한 개발원 조는 우선 그 분야를 우리의 비교우위 및 개도국의 수요를 고려하고 선택하여, 개발원조의 효과성 및 효율성을 높여야 하겠다. 또한, 한국의 발전 시기의 생생한 경험 및 지식을 보유하고 있는 인재 를 활용하여 개발원조로의 국민참여도 제고하는 방안이 될 수 있다.

또한 한국의 원조가 개발도상국에 기여하지 못한다고 생각하는 이유로써 원조규모의 영세성, 원조 방식의 비효율성, 전문성의 부족, 투명성의 미흡 등이 지적되고 있음을 감안하여 이와 같은 분야의 개선 노력이 보다 가속화 되어야 할 것이다. 이와 같은 맥락에서 원조사업의 영세성을 탈피하는 동 시에 작은 규모로 최선의 효과를 내기 위해서는 원조분야와 대상 선정 시 '선택과 집중’의 원칙을 고수할 필요가 있다. 대외원조의 분야와 지역을 많은 원조 공여국들이 자국의 정치적 고려에 의해 단발적으로 결정하는 경향이 있었다. $\mathrm{DAC}$ 회원국들은 대체로 공여국의 비교우위가 있는 분야에서 소수의 수원국에 장기적으로 집중하여 원조하는 것이 효과적임에 동의하고 있다. 또한, 대외원조가 최선의 효과를 내기 위해서는 수원국의 개발계획을 고려한 원조전략을 수립할 필요가 있다.

\section{2) 개발원조의 투명성}

개발원조를 시행함에 있어서 투명성이 절대적으로 중요함은 새삼 강조할 필요가 없을 것이다. 더욱 
이 개발원조는 그 돈이 대규모로 우리의 눈이 미치지 않는 외국에서 쓰이기 때문에 그에 대한 투명 성은 더욱 중요하다고 할 것이다. 그런데 이번 조사결과에서 투명성에 대한 평가가 그리 높지 않은 것으로 나타났다. 이는 대외원조관련 정책이나 활동, 지출과 관련한 정보제공의 부족이나 정보로의 접근성이 떨어지기 때문으로 보이며, 원조관리의 전 과정에 있어서 투명성을 높이고 관련 정보가 충분히 제공될 수 있도록 원조사업 운영상의 개편이 필요하다. 원조사업의 투명성을 높이기 위한 정보의 공개, 계획 수립 및 사업 진행과정의 투명성 진작 등을 위한 노력이 보다 강화되어야 할 것 이다. 특히 원조사업이 개발도상국의 빈곤감소에 기여했는지, 현 정부에서 대외원조를 잘 쓰고 있 는지 등 국민이 원하는 정보를 적시에 투명하게 전달하기 위해 수원국과 공동으로 원조평가 사업을 확대해 시행할 필요가 있으며, 대외원조 정책수립에 있어서 국민이나 전문가들과의 대화나 대외원 조 결과 보고회 등을 정기적으로 갖는 방안도 고려할 만하다.

\section{4. 원조활동에의 참여와 정보의 접근성: 민관협력(PPP)}

\section{1) 민관협력(PPP)의 촉진}

선진국의 경우 절대다수의 국민이 어떠한 형태로든지 개발원조 활동에 참여하고 있으나, 한국의 경 우 그 비율이 상당히 낮았다. 하지만, 다른 한편으로, 국민의 절반가량(48.8\%)이 대외원조 활동과 관련하여 참여할 의향이 있다고 응답한 것은 고무적이다. 문제는 많은 국민이 어떤 방식으로 참여 할지 모른다는 점이다. 해외봉사활동, 기부금 등 원조에 대한 국민참여 방식을 홍보하고 실제로 참 여하도록 유도해야 할 것이며, 개도국 컨설팅이나 대외원조사업에 대한 직접적 참여기회 등도 적극 적으로 개발하고 홍보하여 개발원조에 대한 참여도를 제고할 필요가 있다. 개발원조에 있어 NGO, 연구기관, 재단, 대학, 민간기업 등 다양한 민간 주체들과의 파트너쉽 및 민간 참여의 활성화는 개 발원조에 대한 재원(물적, 인적, 지적)을 확보하는 동시에 개발원조 효과의 지속적 증대를 가져올 것이다.

또한, 우리 국민의 봉사의식이 여타 선진공여국보다 상당히 뒤떨어져 있는 사실을 비추어 볼 때, 세 계시민으로서의 봉사의식을 함양하는 교육도 병행해야 할 것으로 본다. 초등학교에서부터 고등교 육기관에 이르기까지 각각의 연령대에 맞는 봉사의식을 함양하는 교육 프로그램을 개발하고 실행 함으로써 추후 민관협력의 활성화를 높일 수 있을 것이다.

\section{2) 개발원조에 대한 홍보}

개발원조에 대한 홍보는 선진공여국에 있어서 일반 국민의 보다 긍정적이고 적극적인 개발원조에 
대한 태도를 형성하기 위한 중요한 정책수단으로 간주되어 왔다. 네덜란드의 대외협력 교육은 우리 에게 좋은 시사점을 제공한다.

- 네덜란드의 경우 대외원조에 관해 1949년부터 대국민 교육과 홍보를 병행해왔다. 1970년 엔 대국민 홍보 전담기구인 '지속가능한 국제개발을 위한 국가위원회’를 설립하여 대국민 홍보를 담당하게 했다. 이 기구는 네덜란드 사회 내에서 국제협력에 대한 지지를 강화시키고 있다.

- 또 국민의 3 분의 1 인 500 만 명 이상이 개발협력 프로젝트에 직접 참가하고 국민의 반 이상 이 기부하거나, 모금 운동에 참여하거나, 개발 $\mathrm{NGO}$ 의 회원으로 활동하고 있는데, 이러한 참여도는 네덜란드 정부의 자국민에 대한 국제화 교육을 통해 가능해졌다. 곧, 네덜란드 정 부는 네덜란드가 국제 사회의 일원이 되기 위해서는 국제 사회에 기여해야 한다는 국제화 교육을 자국민에게 실시하고 있는 것이다. 국민의 개발협력에 대한 인식을 높이고 참여를 유도하기 위해 인권 교육 같은 추상적 개념에 대한 교육에서부터 개발협력에 적극적으로 참 가시키는 프로그램까지 갖추고 있다.

많은 선진공여국들이 개발협력에 대한 홍보, 교육, 연구, 여론조사 등을 1940 50년대부터 시행한 것에 비해 한국은 매우 늦은 셈이다. 우리나라의 개발도상국에 대한 대외원조의 인지도가 여타 선 진공여국에 비해 낮은 것은 놀랄 만한 사실은 아니지만, 정부의 효과적이고 지속적인 홍보, 교육 노 력이 뒤따라야 할 것이다.

\section{3) 개발원조에 대한 정보의 제공}

개발원조에 대한 정보의 제공은 납세자인 국민에 대한 의무이자, 개발원조에 대한 긍정적인 태도를 형성할 수 있도록 하는데 중요한 무기가 된다. 이번 조사결과에서 나타난 일반 국민의 개발원조 관 련 정보에 대한 수요, 그리고 그들의 정보에 대한 접근 채널 등을 참고하여 개발원조에 대한 정보를 충분히 그리고 즉각적으로 제공할 수 있도록 하는 것이 필요하다. 특히 원조사업이 개발도상국의 빈곤감소에 기여했는지, 현 정부에서 대외원조를 잘 쓰고 있는지 등 국민이 원하는 정보를 적시에 투명하게 전달하기 위해 수원국과 공동으로 원조평가 사업을 확대해 시행할 필요가 있으며, ODA 백서를 만들어 배포하는 것은 개발원조의 투명성 확보에 크게 기여할 것이다.

아울러 수원국의 원조사용 여부, 원조가 빈곤감소에 기여하고 있는지의 여부 등 국민이 원하는 정 
보를 텔레비전, 인터넷, 신문 잡지, 우편 등 국민이 가장 접하기 쉬운 정보전달 매체를 통해 효과적 으로 전달해야 한다. 이들 매체에 개발원조에 대한 section을 마련하여 정기적으로 개발원조 관련 기사나 시론을 제공함으로써 국민의 관심을 유도할 필요가 있다. 또한, 소극적 홍보에서 대외원조 정보를 다양한 방식으로 많이 노출하여 국민이 자연스럽게 대외원조 정보를 접할 수 있는 적극적 홍보로 방향을 바꾸어야 할 것이다. 정부 및 원조기관의 간행물이나 웹사이트는 홍보 효과가 매우 낮은 수준으로 간행물이나 웹사이트 내용의 질적 향상과 더불어 국민이 이들 매체에 손쉽게 접근할 수 있도록 다양한 노력을 기울여야 할 것이다.

\section{V. 맺음말}

한국은 현재 개발원조 분야의 선진공여국으로 발돋움할 필요성을 인식하고, 노력을 기울이고 있다. 무엇보다도 한국은 지난 반세기 동안 축적해온 생생한 개발 경험을 소유하고 있으므로, 기존 공여 국과 차별화된 개발협력을 제공할 수 있을 것으로 기대된다. 국제개발협력의 주요 행위자인 선진 국들은 현재의 개발도상국이 직면한 상황과 매우 다른 환경에서 발전을 이룩했던 반면, 한국과 같 은 신진주자는 근래에 축적한 발전 노하우를 후발주자와 공유함으로써 보다 효과적인 발전전략을 전수해 줄 수 있을 것이다. 이러한 가능성에 대한 인식을 바탕으로 한국은 국제규범에 맞는 개발협 력과 원조를 제공할 것을 목표로 삼아 2010년 OECD/DAC 가입을 위해 노력하고 있다. OECD 가 입국 내 선진공여국의 모임인 DAC에 가입함으로써 한국의 개발원조를 국제규범하에서 재조명하는 단계가 마련될 것이며, 이후 한국이 국제사회의 주요 공여국으로서 활동할 발판을 마련할 수 있을 것이다.

하지만, 한국이 국제규범에 부합하는 개발원조를 수립 · 수행하기 위해서는 먼저 원조 주체자로서 의 국민의식이 확립되어야 한다. 우리나라는 지난 반세기 동안 원조 수원국에서 공여국으로 급속히 성장해왔기에 개발원조 공여의 역사가 짧고, 따라서 신진공여국로서의 새로운 위상에 대한 국민의 이해가 충분하지 못할 수 있다. 이러한 여건하에서 개발원조에 대한 우리 국민의 의식 수준을 살펴 본다는 것은 중요한 의미를 가질 것이다.

이 글에서 소개한 전승훈 외 (2008) 연구보고서는 이러한 인식하에 개발원조에 관한 여론조사를 하 였으며, 그 결과가 정책방향 모색에 시사하는 바를 논의하였다. 한국이 선진공여국으로 발돋움하려 는 시점에서 동 연구결과는 유용하게 쓰일 수 있을 것이다. 하지만 보다 효과적인 개발협력 정책 수 립을 위해서 향후 주기적인 여론조사 및 연구를 시행할 필요가 있다. 특히 정기적으로 조사를 시행 하여 시기적, 지역적인 인식차이를 분석하고, 그 결과 국민의식 변화를 야기하는 요인을 발견하게 
된다면 장기적인 정책을 수립하는 데 도움이 될 것이다. 이러한 의미에서 동 연구가 앞으로의 개발 협력 여론조사 및 연구에 있어 시발점 역할을 하였으면 한다. 또한, 여론은 조사 당시의 정치적, 경 제적, 사회적 여건의 영향을 받는바, 이와 같은 요소와의 연관성 분석도 향후 연구에 있어서는 중요 하게 다뤄져야 할 것이다. 


\section{참고문헌}

\section{1. 국내문헌}

개발협력정책관실. 2008. 『우리나라 대외원조 현황 및 정책방향』. 공적개발원조분야 정부-민간 파트너십 구축방안 모색을 위한 간담회 자료. 외교통상부.

경제협력본부. 2008.『국제 ODA 동향』. 경협 조사자료 P-2. 한국수출입은행.

국정홍보처. 2002.『개도국 개발원조에 대한 사회여론주도층 의식조사』.

동아일보 - 한국국제협력단. 2003. 『한국인의 국제인지도 조사』.

외교통상부. 2007. 『대국민여론조사』.

조인스닷컴 - 리서치앤리서치. 2006. 『제29차 Joins-R\&R 주간사회지표조사』.

최민경. 2008. 『우리나라 개발원조의 민관협력 활성화 방안 : PPP와 개발컨설턴트 활용 을 통한 민간과의 파트너십 강화』. 연구자료 정책연구 2008-5-83. 서울: 한국 국제협력단.

한국개발전략연구소. 2007. 『한국적 개발협력 프로그램 발전방안 연구』. 연구자료 정 책연구 연구자료 정책연구 2007-2-52. 서울: 한국국제협력단.

\section{2. 국외문헌}

European Commission. 2007. "Europeans and Development Aid”.

Environics Research Group. 2004. Canadian Attitudes Toward Development Assistance: Focus Canada Omnibus. Canadian International Development Agency. 
Mc Donnell, H. B. Solignac-Lecomte and L. Wegimont. 2003. “Public

Opinion and the Fight against Poverty". an OECD Development Centre Study.

Swedish International Development Cooperation Agency. 2006. Swedish Viewpoints on Development Cooperation.

Public Affairs Group. 2005. Overseas Aid Study. Australian Government Overseas AID Program.

http://www.fredskorpset.no/en/FK2/

http://www.cmi.no/

http://www.worldbank.org/ 